\title{
Erken 21. Yüzyılda Mekansal ve Toplumsal Kimliklerin Değişimini Büyük Ölçekli Konut Projeleri Reklamları Üzerinden Okumak
}

\author{
Seda Kaplan Çinçin ${ }^{1 *}$
}

Öz

Mekan ve toplumsal yaşam dönemlerin egemen ideolojilerinden bağımsız okunamamaktadır. Modernleşme hareketiyle başlayan uygulamalardan günümüzün neoliberal politikalarıyla uygulanan mekan üretimi ve bununla birlikte toplumsal yapıyı şekillendirmeye yönelik uygulamalar, her ideolojinin kendi mekanı ve toplumunu belirlemeye çalıştığını Türkiye örneğinde de ortaya koymaktadır. Konut üretimindeki değişimin sonucu büyük ölçekli konut projelerinin sunduğu mekansal ve toplumsal yapı ideolojik aygıt medyanın bir aracı olan reklam aracılığıyla toplumun beğenisine sunulmaktadır. Reklamlarda sunulan büyük ölçekli konut projelerinin mekansal ve toplumsal kimlikleri değiştirmekte olduğu görülmektedir. Bu yazı kapsamında, mekansal ve toplumsal kimliklerin değişimi, son on sene içerisinde yayınlanmış ve toplumun büyük bir kesimine ulaşmış büyük ölçekli konut projelerinin gazate ve TV reklamlarında sunulanlar üzerinden, göstergebilimsel kavramlarla ele alınacaktır.

Anahtar Kelimeler: Büyük Ölçekli Konut Projesi, Konut, Reklam, Kimlik, Mekansal Kimlik Değişimi, Tüketim Toplumu

\section{Reading the Change of Spatial and Social Identities in the Early 21st Century through Advertisements on Large-Scale Housing Projects}

\begin{abstract}
Space and social life can not be read independently of the dominant ideologies of the periods. From the applications that started with the modernization movement, the applications for shaping the space production and the social construction applied with the neoliberal policies of today, demonstrate that every ideology tries to determine its own space and community İn Turkey case. The resulting spatial and social formation of large-scale housing projects as a result of the change in housing production is presented to the public through advertisements as an intermediary of the ideological device media. It is seen that the spatial and social identities of large-scale housing projects presented in advertisements are changing. In this article, changing of spatial and societal identities will be discussed with semiotic concepts through the advertisement of large-scale housing projects published in the last five years and reaching to a large part of the society in the published gazette and TV commercials.
\end{abstract}

Keywords: Big Scale Housing Project, Advertisement, Identity, Change of Spatial Identities, Consumer Society

\footnotetext{
${ }^{1}$ Kocaeli Üniversitesi, Mimarlık ve Tasarım Fakültesi, Mimarlık Bölümü

* Illgili Yazar / Corresponding Author: kplnseda@gmail.com

Gönderim Tarihi: 31.05.2017

Kabul Tarihi: 27.03.2018
} 


\section{GíRiş}

İnşaat sektörü ve konut üretim biçimlerinin değişimiyle birlikte mekansal ve toplumsal değişimleri de anlamak için öncelikle mekanın toplumsal ile olan ilişkisine bakmak gereklidir. Çünkü, mimarlık pratiğinin ana nesnesi mekan ve mekanın üretimi, toplumsal ilişkilerden bağımsız düşünülemez. Harvey (2013)'e göre, kent, toplumsal davranışı ve mekansal biçimiyle birlikte ele alındığında anlaşılabilir çünkü bir mekansal biçim yaratıldığında, toplumsal sürecin gelişmesini kurumlaştırmaya ve kısmen de belirlemeye çalışır. Ayrıca, Lefebvre (2014), mekansal pratiğin, mekan temsillerinin ve temsil mekanlarının, mekan üretimine, niteliklerine ve özelliklerine, toplumlara ve dönemlere göre farklı şekillerde etki ettiklerini belirtir. Mekan bir üst yapının koşulu ve sonucudur, yani devlet ve onu oluşturan kurumların her biri, bir mekan varsayar ve bunu kendi intiyaçlarına göre düzenler. Dolayısıyla, mekan, kurumların ve bu kurumların tepesinde bulunan devletin önsel koşuludur. Castells (2014)'de mekana kent ölçeğinden yaklaşırken, kentsel çelişkileri toplumsal dinamiklerle ilişkilendirerek ele alırken kenti anlamanın ancak sınıf, siyaset ve iktidar arasındaki ilişkilerin kavranmasıyla yapılabileceği üzerinde durmuştur.

Bu bağlamda, Türkiye'deki mekanın ve toplumsal yaşamın üretimini dönemlerin egemen ideolojilerinden bağımsız okuyamayacağımızı belirtebiliriz. Modernleşme hareketiyle başlayan uygulamalardan günümüzün neoliberal politikalarıyla uygulanan mekan üretimi ve bununla birlikte toplumsal yapıyı şekillendirmeye yönelik uygulamalar, her ideolojinin kendi mekanı ve toplumunu belirlemeye çalıştığını Türkiye örneğinde de ortaya koymaktadır.

Avrupa'da ortaya çıkan ve gelişen modernizimle birlikte Türkiye'de de modernleşme ve batılılaşma hareketlerine başlanmıştır. Modern yaşam koşullarına uygun olarak yeniden gelişen yaşam alanlarının en etkili alanı konutun değişiminde ve kent planlamalarında olmuştur (Özgen Kösten, 2016). Kentsel ölçekteki kamusal yapıların tasarlanması da toplumu modern yaşamla tanıştırmaya yöneliktir. Ayrıca, Cumhuriyet ideolojisinin bütünleştirici bir mimarlık oluşturma çabası mimarlık tarihi yazınında da kendini gösterir. Erken Cumhuriyet dönemi mimarlığı ağılıklı olarak resmi yapılar aracılığı ile tanımlanmıştır ve homojen bir mimarlık hareketi kurgulamıştır. Bu nedenle erken Cumhuriyet dönemi mimarlığı yerellik, bölgesellik ve bireyselliğin etkileri göz ardı edilerek, siyaset ve ideolojiye odaklanarak yazılmıştır (Çıkış, 2011).

Cumhuriyet döneminin modernleşme ideolojisiyle birlikte fiziki çevre, konut ve toplumsal yapıyı dönüştürdüğü gibi günümüz egemen ideolojisi de küreselleşme ve neoliberal politikaların etkisiyle yeni bir toplumsallık ve fiziki çevre tariflemeye başlamıştır. Erzen (2004)'e göre, Türkiye'de mimari uygulamalar doğrudan politik ve ekonomik çıkarlara ilişkin olarak koşullanmaktadır.

Küreselleşmeyle birlikte gelişen dünya kenti kavramı kentsel kimlik, kentsel imaj, çevresel kalite gibi kavramlar üzerinden bir dönüşümü başlatmıştır. Türkiye'de özellikle 2000'li yıllardan sonra iktidar ve sermayenin birlikte sürdürdüğü mekan üretimi politikalarını Harvey ve Lefevbvre'nin çalışmalarına bakarak kapitalist kent üretimiyle ilişkilendirebiliriz. Kent Deneyimi kitabında kapitalist düzende kent sürecine ilişkin farklı bir teorik ve tarihsel yaklaşım getirilip getirilemeyeceğini tartışan Havrvey, Lefebvre'in kent sürecinin kapitalizmin dinamiklerinde önemli bir yeri olduğu görüşünü, sermayenin kentleşmesi üzerine çalışmalarıyla kanıtlamış olduğunu vurgulamaktadır. Diğer bir yandan, Lefebvre'in kapitalizmin mekan üretimi ile devamlılığının sağlandığı söylemine, kapitalizmin yalnızca mekan üretimi ile değil aynı zamanda mekan üzerinde hakimiyet kurduğu için de devamlılığını sağladığını söylemektedir. Bu noktada, Harvey ve 
Lefebvre'in görüşlerinden de anlıyoruz ki kapitalizm hem mekan üretimi hem de mekan üzerindeki kontrolü ile devamlılığını sağlayabilmektedir, mekan üretimi ve mekan üretimin yapısı sermayenin yeniden birikimi doğrultusunda işlemektedir. Bu bağlamda, Türkiye'de kentleşme ve mekan üretimi süreçleri ve biçimlerine bakıldığında sermaye birikimiyle birlikte kapitalizmin devamlılığı için sürecin çalıştığını görebilmekteyiz. Özellikle İstanbul bu anlamda iki teorinin de örnek alanı olarak değerlendirilebilir.

Gecekondudan büyük ölçekli konut projelerinin inşa edilmesine kadar bütün üretim biçimlerinde iktidar ve sermayenin kararları etkili olmuştur ve olmaktadır. Özellikle İstanbul, hem ekonomik hem de toplumsal ilişkiler bağlamında değişen konut üretimlerini hem en yoğun yaşayan hem de bu üretimden en yoğun etkilenen kenttir. Diğer kentlerde ise İstanbul'un benzeri durumlar daha farklı ölçeklerde olsada benzer şekillerde karşımıza çıkmaktadır. 2000'lerde konut üretimi her şehirde aynılaşan projelerle karşımıza çıkmakta ve bu üretim mekânsal ve toplumsal kimlikleri etkilemektedir. İstanbul'un öncüsü olduğu bu değişim, medyanın işleyişi ile moda haline gelerek yayılmakta ve arzu nesnelerine dönüştürülmektedir.

Konut üretim biçimlerinden son dönemde karşımıza çıkmış olan büyük ölçekli konut projelerinin sunduğu mekansal ve toplumsal yapı ideolojik aygıt medyanın bir aracı olan reklam aracılığıyla toplumun beğenisine sunulmaktadır. İnşaat sektörünün medyayı araç olarak kullanmasının sebeplerinden biri, 2000'lerde Türkiye'nin ekonomik gücü haline gelen inşaat sektörünün arz yönlü olarak ürettiği konut projeleri için potansiyel tüketici oluşturabilmektir. Medya, projeleri, tüketicinin intiyaç duyduğu meta olarak gösterir ve tüketimi arzulatır. Diğer bir sebep ise, devlet ve sermayenin büyük ölçekli konut projeleri ile gerçekleşebilecek yeni bir toplumsallık ideolojisini medya aracılığı ile temellendirebilmektir çünkü medya toplumun tüketim toplumuna dönüşmesini sağlayan en etkili araçtır.

$\mathrm{Bu}$ yazı kapsamında, mekansal ve toplumsal kimliklerin değişimi, son on sene içerisinde yayınlanmış ve toplumun büyük bir kesimine ulaşmış büyük ölçekli konut projelerinin gazate ve televizyon reklamlarında sunulanlar üzerinden, göstergebilimsel kavramlarla ele alınarak, büyük ölçekli konut projelerinin mekansal ve toplumsal kimlikleri değiştirmekte olduğunun gösterilmesi amaçlanmıştır. Bu kapsamda, ilk olarak medya ve reklam kavramlarından bahsedilerek, reklamların işleviyle bağlantılı olarak konut projesi reklamlarının analizi için kavramsal temel oluşturulmaya çalışılmıştır. Yazının ikinci bölümünde çalışma kapsamında seçilmiş olan büyük ölçekli konut projeleri üzerinden mekansal ve toplumsal kimlik meselesi araştırılmıştır. Büyük ölçekli konut projeleri reklamlarında kullanılan satış stratejilerinin, mekansal ve toplumsal kimlikle ilişkisinin anlaşılmasına olanak sağlayacağı düşünülen son yıllarda üretilmiş ve reklamı yapılan projelerden bu çalışma kapsamında yedi proje örnek olarak seçilmiştir. Bu seçim yapılırken aynı şirket tarafından farklı şehirlerde tasarlanmış proje reklamları seçilerek; aynı sermayenin farklı yerlerde, farklı potansiyel tüketicilere yönelik tasarladığı projelerin konseptlerini karşılaştırılabilmesini sağlayacağı, projelerin kent kimliği açısından ele alınmasına olanak vereceği ve reklam stratejilerinin toplumsal kimlik üzerindeki etkisinin okunabileceği düşünüldüğü için tercih edilmiştir.

\section{MEDYA VE REKLAM}

Modern medyanın kültürel işlevi, başkalarının dünyalarını, onların hayatları ile bizimkileri kavranabilir bir bütünün dünyası halinde inşa ettiğimiz toplumsal bilginin, toplumsal imgenin sağlanması ve seçici bir şekilde inşa edilmesidir. (Hall, 1994, akt. Dağtaş, 2012). Kısacası, kitle iletişim araçlarından oluşan medyanın işlevi, bir ideolojik aygıt olarak toplumu yapılandırmaktır. Althusser (2014)'e göre, devletin ideolojik 
aygıtlarının işleyişinde tüm aygıtlar, "üretim ilişkilerinin yeniden üretimi, yani kapitalist sömürü ilişkilerinin yeniden üretimi” hedefine yöneliktir.

Yapısalcı yaklaşım ve göstergebilime göre ideoloji bir göstergeler sistemidir. Göstergebilim (semiyoloji) göstergelerle, kodlar ve alt kodlar halinde düzenlenmiş ideolojiler evrenini belirtir (Dağtaş, 2012). Bu bağlamda, devlet ve sermayenin yarattığı değerler yani onların göstergeleri topluma medya aracılığıyla aktarılır. Toplumsal bir varlık ve ortak bir kültür gereksinimi duyan birey, bir toplumsal yere sahip olma isteği duyar. Toplumda kendine bir yer arayan bireye imgesel bir yer, kitle iletişim araçları aracılığıyla verilebilir (Williamson, 2001).

Kapitalist düzende medya, toplumu yönlendirici rolüyle devletin ve büyük sermayenin istediği düzeni ve yaşamı oluşturur. Toplumun her kesimine ulaşabilir. Toplumun ilgisini çeken konuları kullanırken bu ilgileri ve yaşamı da şekillendirebilir güce sahiptir. Medyanın bu gücünü devlet ve büyük sermaye ortaklarıyla olan ilişkisi belirler. Dağtaş (2012)'a göre medya, kapitalist toplumlarda çoğunluğun rızasını sağlamaya yardımcı olan bir üst yapı kurumudur. Bütün medyayı kaplayan ve hiçbir sınırı bulunmayan reklamcılık da açıkça özerk bir varoluşa ve muazzam bir etkileme gücüne sahip geniş bir üst yapıyı oluşturur (Williamson, 2001).

Reklamcılık, 1980'li yıllarda başlayıp 1990'lı yıllarda çeşitlenen ve artan, 2000'li yıllarda ise yayılan tüketim kültürüyle birlikte gelişip büyümüştür. Tüketim kültürünü yayan imajlar ve göstergelerle dolu medya metinlerinin (köşe yazıları, hafta sonu ekleri, televoleler, diziler, vb.) yanı sıra reklam metinleri de göstergeler, imajlar, yaşam tarzı sunumlarıyla doludur. Reklam metinleri, salt ürün tanıtan metinler değil, kültürel boyutu ile birlikte ideolojik metinlerdir. Reklamcılık ve tüketim kültürü, hem kapitalizmin ekonomik yeniden üretimi hem de ideolojik yeniden üretimde rol almaktadır. Aynı zamanda toplumsal yeniden üretimi etkilemektedir (Dağtaş, 2012).

İkna edici, bilinçaltına seslenen, yönlendiren gibi nitelikleri olan gündelik yaşamın bir parçası olmuş reklam iletileri küresellikle birlikte her yerdedir, toplumsal bir olgudur ve kendine özgü diliyle tüketim biçimlerini, davranışları etkiler, değiştir (Küçükerdoğan, 2011). Ayrıca, reklamlar, toplumun gerçek sorunlarını belirsizleştirir ve onlardan kaçınırlar. Toplumun temel sınıfsal yapısı üzerinde toplumsal farklılık sistemleri yaratırlar. Toplumun bugünkü durumunda parayla ve onun kazanılma biçimiyle ilgili temel sorunlar, parayla değil, ürünlerle satın alınacak anlamlar, imgeler, yaşam tarzları içinde kaybedilir (Williamson, 2001).

Baudrillard (2014)'a göre, reklam sistemin ayrılmaz bir parçası haline gelmiştir ve reklam her ne kadar anlamsız ve işlevsiz olarak görünse de sistem açısından işlevseldir. Oysa, reklam bir yan anlamdan başka bir şey değildir. Üretim ve tüketim aşamalarında hiçbir rolü olmamasına rağmen "nesneler sistemi"nin ayrılmaz bir parçasıdır. Çünkü reklam sadece tüketim odaklı bir şey değil aynı zamanda bir tüketim nesnesidir. Reklam ve tüketim toplumu iç içedir çünkü tüketim toplumunda "tüketim, intiyaçtan çok prestij, farklılık, bir gruba ait olma, kimlik edinme ve sınıf atlama gibi simgesel değerler adına yapılmaktadır (Dağtaş, 2012). Reklam metinleri tüketicinin ürünü veya hizmeti kullanarak "sınıf atlayacağı", "yaşamının olumlu anlamda değişeceği”, "bir gruba ait olacağı", ya da "farklı olacağı" gibi iletiler sunmakta, ürünün tanıtımı ise geri planda kalmakta ya da hiç yer almamaktadır.

Reklamın diğer boyutu ise kültürel ve politik bir metin olma özelliğidir. Reklamcılık, ürün ve hizmetleri pazarlarken, kültürel ve ideolojik temsillere ve mitlere başvurur (Dağtaş, 2009). Ancak, Levi-Strauss (2013)'a göre, kültürün gerçekten kendisi olabilmesi ve bir 
şey üretmesi için, söz konusu kültür ve mensupları, özgünlüklerinden ve hatta bir ölçüde başkaları üzerindeki üstünlüklerinden emin olmalıdır; kültür sadece eksik iletişim koşullarında bir şey üretebilir. Dağtaş (2009) reklamın kültürel bir metin olmasıyla ilgili diğer boyutu; reklam bildirilerinin toplumsal ve kültürel değişimlere bağımlı olmasıyla ilişkilendirmiştir. Toplumsal ve kültürel değişimlere dair imajlar reklama yansımaktadır. Bir toplumun reklam tarihine bakılarak, o toplumun kültürel ve toplumsal değişimleri hakkında fikir edinilebilir.

Reklamlar, tanıtımını yaptıkları ürünleri, tanıtmaktan çok o ürüne dair yarattıkları imgeyi gerçek kılarak tüketicilerin zihinlerinde yer etmesini sağlarlar. Williamson (2001), reklamların kendi tüketicilerini yarattıklarını ve tüketiciye neye benzediğini söylediklerini belirtmiştir. Büyük ölçekli konut projelerinin reklamlarında rastladığımız şey tam da budur. Neredeyse her konut projesi üzerine bir konsept giydirilmiş olarak sunulur ve o konseptin sunduğu yaşam da sizin bu zamana kadar arzu ettiğiniz yaşam olarak yansıtılır. Bu gösterilen yeni yaşam da kapitalizmin devamılığı için tasarlanmış bir yaşam biçimidir. Bu yaşam biçiminde, insanlar bireyselleştirilir, gündelik hayat konut projelerinin içine sıkıştırılmış olarak tüketmek üzerine kurulur. Tükettikçe de arzuların doyuma ulaşabildiği kurgusu, reklamların gücüyle zihinlere yerleştirilir. Konutun kendisi artık bir tüketim nesnesidir ve konutla birlikte sunulan donatılar da tüketim nesneleridir.

Büyük ölçekli konut projeleri reklamlarında, genellikle projelere ait görüntüler potansiyel tüketicilere özgü imgelerle tasarlanarak karşımıza çıkarılır. Reklamı yapılan büyük ölçekli konut projelerinde, konutun mimari özellikleri, yer bilgisi gibi asıl unsurlardan bahsedilmezken, o projede konut edinmenin ayrıcalığı, sağlayacağı prestij, çoğu projenin bahsettiği yeni yaşam kültürü konsepti gibi tüketim toplumuna özgü kavramların vurgusu yapılır. Projenin tüketim toplumuna ait donatılarla - alışveriş merkezi, spor merkezleri, yeme içme mekanları, vb.- tasarlanmış bireysel yaşam alanlarında, yeni yaşam kültürüne davet edilirler.

Bu bağlamda, Türkiye'de yaşanan kentleşmenin toplumsala etkisini medyada karşımıza çıkan örneklerle okuyabileceğimizi söyleyebiliriz. Ayrıca, reklamlar, topluma yeni kimlikler dağıtır, toplumu kendi ihtiyaçları doğrultusunda şekillendirir. Bundan dolayı, devlet ve sermaye tasarladığı büyük ölçekli konut projelerininin - kapitalizmin mekanı - ve yaşam tarzının - tüketim toplumu - toplumda arzulanmasını ve bir ihtiyaca dönüşmesini reklam iletişimiyle sağlamaya çalışmaktadır.

\section{BÜYÜK ÖLÇEKLI KONUT PROJELERI REKLAMLARINDA KIMLIK}

Kentlerin farklı karakterleri kent kimliği, kent profili ve kent imgesi kavramlarıla açıklanmaktadır (Önem \& Kılınçaslan, 2005). Benzerler arasında kıyaslamayı sağlayan ve benzerine göre sahip olunan ayırt edici özellikleri ortaya koyan kimlik kavramı kentler ve mimari ürünler açısından öncelikle görsel boyutuyla ön plana çıkan, ayrıca doğal, coğrafi, kültürel ürünler ve sosyal yaşam normlarını da kapsayan çok geniş bir tanımı içermektedir. Kentsel kimlik ve kentsel imgeler, kent mekanı içerisinde tarihsel süreç boyunca biçimlenmektedir (Ulu\&Karakoç,2004). Kent kimliği; kente ait olan, kenti diğerlerinden farklı kılan ve değer katan, kendine özgü unsurların oluşturduğu bir bütündür (Birol, 2007).

Son dönemde ülkemizdeki kentlerin özgün kimliklerini kaybetmekte olduklarından sıklıkla söz edilmektedir. Yerel yönetimlerin kentsel dönüşüm projeleri gibi çalışmalarla kaybedilmiş bulunan kimliğin kentlerimize yeniden kazandırılabilmesi amaçlandığı belirtilmektedir. Ancak, kente yapılan çeşitli olumsuz müdahalelerle önce o kentin özgün kimliğini kaybetmesine yol açmak, daha sonra da ona yeni bir kimlik 
kazandırmak, kentin tarihsellik boyutuna ve kentsel belleğin sürekliliğine zarar verecektir. Çünkü, bir kent geçmişine ait özellikleri ile çağdaş gereksinimlerini uygun fiziksel ortamlarda kaynaştıramadığı zaman, tarihsel ve kültürel süreklilik zedelenir ve kentteki özgün kimliğin kaybı genellikle bu durumda ortaya çıkar. Kent kimliğinin oluşumu için bir süreç gerekir (Birol, 2007).

Bir toplumda ve bir yörede ortaya çıkan kent kimliğinin en belirgin öğesi olan konut biçimlerinin, hem toplumun hem çevrenin özelliklerinden etkilendiği ve bireylerin konut konusundaki seçimlerini bu etkiler altında yaptığı bilinmektedir (Çıkış, 2011). Küreselleşme ile birlikte tanıştığımız tüketim toplumunda ise konutun kullanım değerinin yerini meta değerinin aldığı günümüzde konut üretim biçimleri tamamen farklılaşmaya başlamıştır. Yere ve toplumsal yaşama özgülük yerine her kentte tek tipleşen konut alanları ve bu konut alanlarının sunduğu toplumsal yaşam biçimi kentsel ve toplumsal kimlikleri kapitalizmin yeniden üretimi çerçevesinde değiştirmektedir. 2000 'li yıllarda ortaya çıkmış olan büyük ölçekli konut projelerinin kentsel kimliğin devamlıığını göz etmemesine rağmen, birbirinin benzeri konut projelerinin satış stratejilerinde kentsel ve toplumsal kimlik öğelerini sahte bir biçimde kullandıklarını görmekteyiz.

Günümüzde birçok farklı konut biçimini bir arada bulunmaktadır. Örneğin, büyük sermayenin ürettiği toplu konut projeleri, kooperatifler, orta boy sermayenin konut siteleri, devletin ve yerel yönetimlerin toplu konut projeleri, yapsatçı sistemle üretilmiş apartmanlar, değişik türlerdeki gecekondu alanları, gecekondu yapsatçı apartmanları ve mafyalaşmış ve siyasallaşmış gecekondu alanlarının bütünü İstanbul kent dokusunu oluşturan, bununla birlikte toplumsalı da oluşturan konut biçimleridir (Tekeli, 2013). Küçük, orta ve büyük ölçeklerde farklı konut üretim biçimleri gerçekleşse bile kentsel kimliğe etkisinin en büyük olduğu projeler büyük ölçekli olanlardır. Küreselleşmeyle birlikte gelişen dünya kenti kavramı kentsel kimlik, kentsel imaj, çevresel kalite gibi kavramlar üzerinden bir dönüşümü başlatmıştır.

Yazı kapsamında "büyük ölçekli konut projeleri" olarak, 2000'lerden sonra ilk olarak İstanbul'un kentsel dokusunda ortaya çıkmış ve diğer kentlerde de inşa edilmeye başlamış, kentsel dokuyu ve kentsel yaşamı büyük oranda etkilemiş projelerden bahsedilmektedir. Genellikle kent çeperlerinde tasarlanan bu karma kullanımlı projeler, kendi sınırları içerisindeki alışveriş merkezi, spor salonu, kafe ve restoranlar gibi donatılarla tüketicisinin bütün gündelik intiyaçlarını karşılayacağını söylerken "yeni yaşam tarzı" konseptini ortaya çıkarmışlardır. Bu konsept, kapitalizmin devamlılığı için geliştirilmiş tüketim toplumu yaşamıdır. Büyük ölçekli konut projeleri olarak adlandırdığımız bu proje grubu göstergeler ve imgeler üzerinden konseptlerini geliştirirler çünkü tüketim toplumunda artık konut kavramından çok konut sahibi olmanın getireceği ayrıcalık değerlidir.

Örneğin, Perouse (2007) bildirisinde, Başakşehir'de yaşananları İstanbul'un çeperlerinde yeni bir "kentsel kimlik" yaratma çabası olarak ele almıştır. Başakşehir'i, projenin amacı olarak söylenen sosyal konut üretmenin ötesinde, istenilmeyen unsurlardan arındırımış yeni bir şehirli toplumu yaratmayı hedefleyen bir siyasi hamle olarak değerlendirmiştir. Bu duruma benzer şekilde bir çok kentte 2000'lerde üretilmeye başlanmış büyük ölçekli konut projeleri mekansal kimlikleri değiştirirken, sundukları mekanlar aracılığıyla egemen ideolojinin arzu ettiği toplumsal kimlikleri oluşturmaya başlamıştır, bu durumun işleyişi ideolojik aygıt medya aracılığıyla güçlendirilmektedir.

İdeolojik aygıt medyanın araçlarından reklamlar, ortak bir beğeni ve arzu dünyası yaratarak aslında bireyleri ve yaşamları tek tipleştirir. Büyük ölçekli konut projesi 
reklamları açısından ise bu durum daha vahimdir, çünkü reklamlarda sunulan projeler çevreyi de tek tipleştirmektedir. Özellikle, İstanbul arz yönlü olarak üretilen ve reklamlar aracığıyla talep edilir hale getirilen projelerle dolup taşmaktadır. Bu bağlamda, Türkiye'de büyük ölçekli konut projelerinin reklamları, potansiyel tüketicisinin değerlerine göre hazırladıkları reklam bildirilerini, özlemini duyduğunuz yeni yaşam olarak tüketiciye sunarak aslında yeni bir kimlik inşa etmeye başlamışlardır.

Bu noktada, bu çalışmanın konusu olan konut projeleri reklamlarındaki mekansal ve toplumsal kimliklere yönelik araştırma konusunun önemini ortaya çıkaracağı düşünülen Jale Erzen'in günümüzün konutuna yönelik yönelttiği soruya yer vermekte fayda var:

“acaba bugünün konutu yer'in farklılığına, bireyin farklılığına, ve bireyin özgürlüğüne, özgür düşünmesine, dolayısıyla toplumsal alana özgür eylemi ile katılmasına izin veriyor mu? Yoksa bunun karşısında bireyi, kimliği ve kimliklerin bir araya geldiği, karşı karşıya geldiği, diyalog kurduğu farklılıklar alemini yok etmeye ve standartlaştırmaya mı planlanmış görünüyor? Farklılık, yüz katlı ve birbirinin kopyası barınaklar içeren kulelerin tepesine geçirilen şapkalar, maskelerden mi ibaret?" (Erzen, 2004).

\section{BÜYÜK ÖLÇEKLI KONUT PROJELERININ REKLAM ÇÖZÜMLEMELERI}

Büyük ölçekli konut projeleri reklamları üzerinden mekansal ve toplumsal kimliklerde yaşanan değişimi görmek için son on sene içerisinde reklamı yayınlanmış yedi adet proje reklamı örneklem olarak seçilmiştir. Bu projelerin hepsi aynı inşaat firmasına ait projelerden seçilmiştir. Bu örnek seçimi, aynı sermayenin farklı yerlerde ve farklı potansiyel tüketicilere yönelik tasarladığı projelerin konseptlerini karşılaştırma olanağı vereceği için tercih edilmiştir (Şekil 4.1). Ayrıca seçilen projelerin mekansal ve toplumsal kimlik açısından ele alınabilecek farklı noktalara vurgu yapabilmeye olanak verdikleri için büyük ölçekli konut projelerine dair yayınlanmış olan gazete reklamlarından oluşan bir veri tabanı içerisinden seçilmişlerdir. ${ }^{2}$

\footnotetext{
${ }^{2}$ Kaplan, Seda, Erken 21. Yüzyılda Üretilen Büyük Ölçekli Konut Projelerinin Tanıtımında, Kentsel Konum Manipülasyonu, İstanbul Örneği, Yüksek Lisans Tezi, MSGSÜ, FBE, İstanbul, 2016
} 

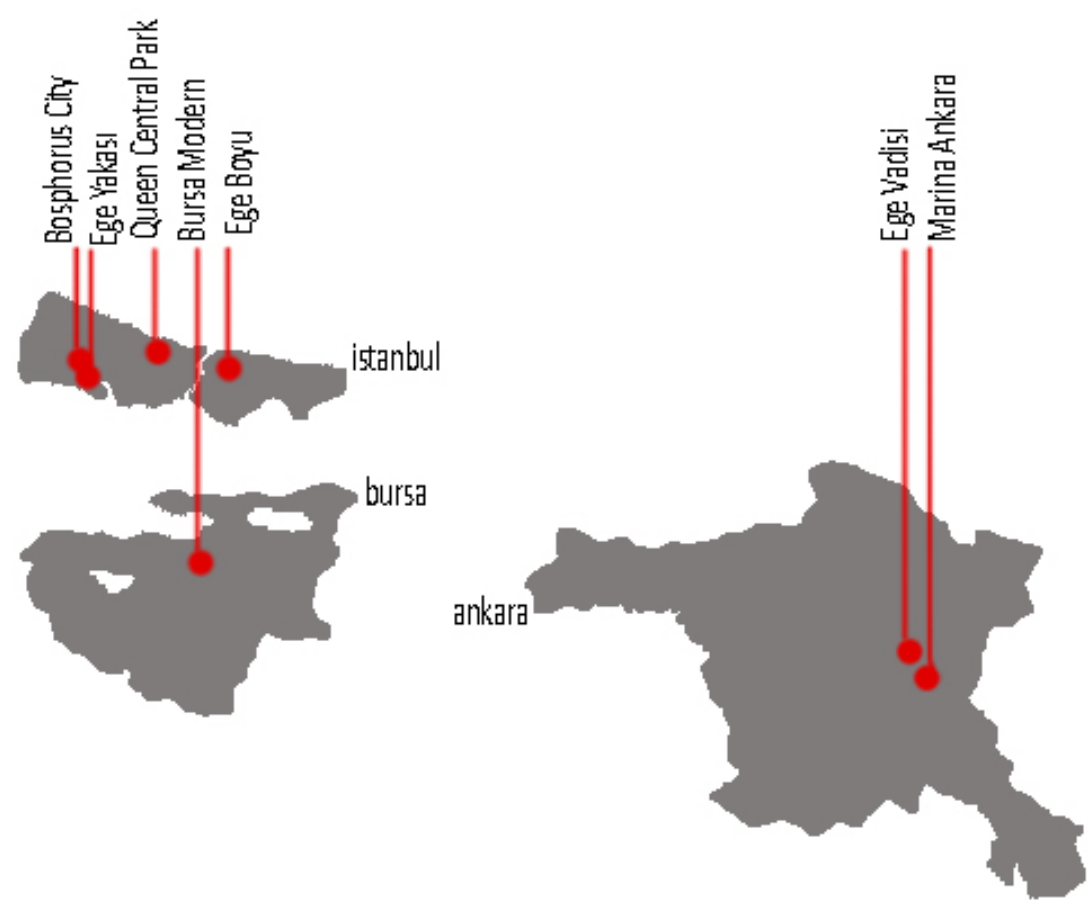

Şekil 4.1: Projelerin Konumları

Reklamların çözümlemesinde yöntem olarak göstergebilime başvurulmuştur. Reklamının göstergebilimsel açıdan çözümlemesini yapmak için, reklamdaki gösterge ve gösteren ${ }^{3}$ ilişkileri ile reklam bildirisine yani reklamdaki yananlama bakmamız gereklidir.

Sassure (2014)'e göre gösterge, gösteren ve gösterilenden oluşmaktadır. Genel bir ifadeyle gösterge, kendi dışında bir şeyi temsil eden ve dolayısıyla bu temsil ettiği şeyin yerini alabilecek nitelikte olan her çesit biçim, nesne, olgu, vb. olarak tanımlanır. Saussure (2014) göstergenin, kendi fiziksel biçiminden ve çağrıştırdığı zihinsel bir kavramdan oluştuğunu ve bu kavramın dış dünyanın bir kavranışı olduğunu söyler. Saussure, için gösterilen bir nesne değil, ama nesnenin zihinsel tasarımıdır (Barthes, 2014). Gösterilen anlama sürecinde devreye girer ve göstergeyi kullanan ya da göstergeye maruz kalanın anladığı şeydir. Gösterilenin ne olduğu aslında ne gösterilmek ya da anlatılmak istendiğiyle ilgilidir. Gösteren ise gösterilen için bir aracıdır. Gösterilen anladıklarımızken, gösteren ise şeylerdir yani nesne, görsel metin, yazılı metin ya da bunların bir arada kullanımıdır.

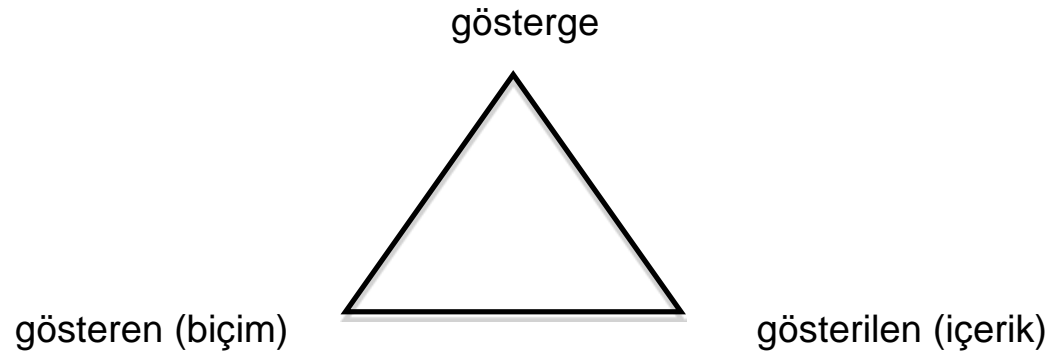

Şekil 4.1: Roland Barhes'a göre gösterge şeması

Yazlları Istanbul: Ithaki Yayınları ve Barthes, R. 2014. Göstergebilimsel Serüven 7 dú. İstanbul: Yapı Kredi Yayınları. 
Reklam metinleri tüketiciyi etkilemek için kendi göstergeler sistemini tasarlar. Bu yüzden, reklam iletilerinde görsel ve dilsel göstergelerin çözümlenmesinde, göstergelerin birbirleriyle kurdukları bağıntı yani reklamın yapısı çözümlenmelidir. (Küçükerdoğan, 2011). Bu kapsamda, seçilen örnekler tablolaştırılarak, reklam içeriğinde tasarlanmış gösterenler ve gösterilenlerin aracılığıyla çözümleme yapılcak ve ve elde edilen veriye göre mekansal ve toplumsal kimlik hakkında yorum yapılabilmesi sağlanacaktır.

\subsection{Queen Central Park Konut Projesi Reklamı}

İlk olarak ele alınacak proje Queen Central Park projesidir. Bu proje reklamının seçilmesindeki sebep, projenin tasarlandığı bölge olan Bomonti'nin zaten sahip olduğu mekansal ve tarihsel kimlik yerine yeşil alan açısından New York'a ait imge değeri yüksek Cental Park'la ilişkilendirilmeye çalışılmasının, kentsel kimliğin bir yandan yok sayılırken bir yandan da başka bir kentsel kimliğin parçası olan değeri projede satış stratejisi olarak kullanılmasının mekansal kimlik okuması açısından önemli bir örnek olarak görülmesidir. Diğer yandan ise reklamda tüketiciye İngiltere Kraliçesinin imgesinin seslenmesi de prestij değerinin konutun kullanım değerinin önüne geçtiğini göstereceği için seçilmiştir.

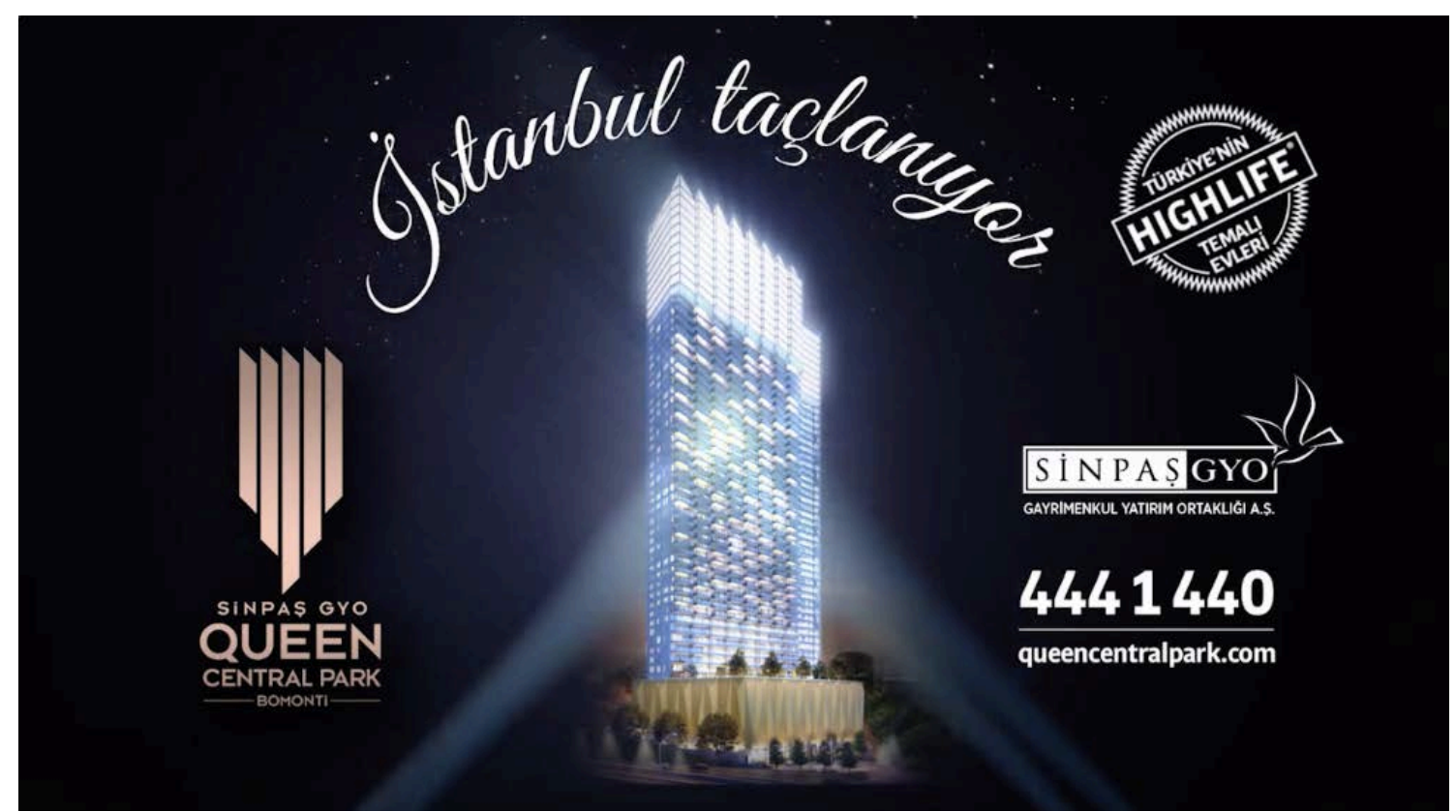

Şekil 4.3: TV reklam filminden ekran görüntüleri (URL 1) 


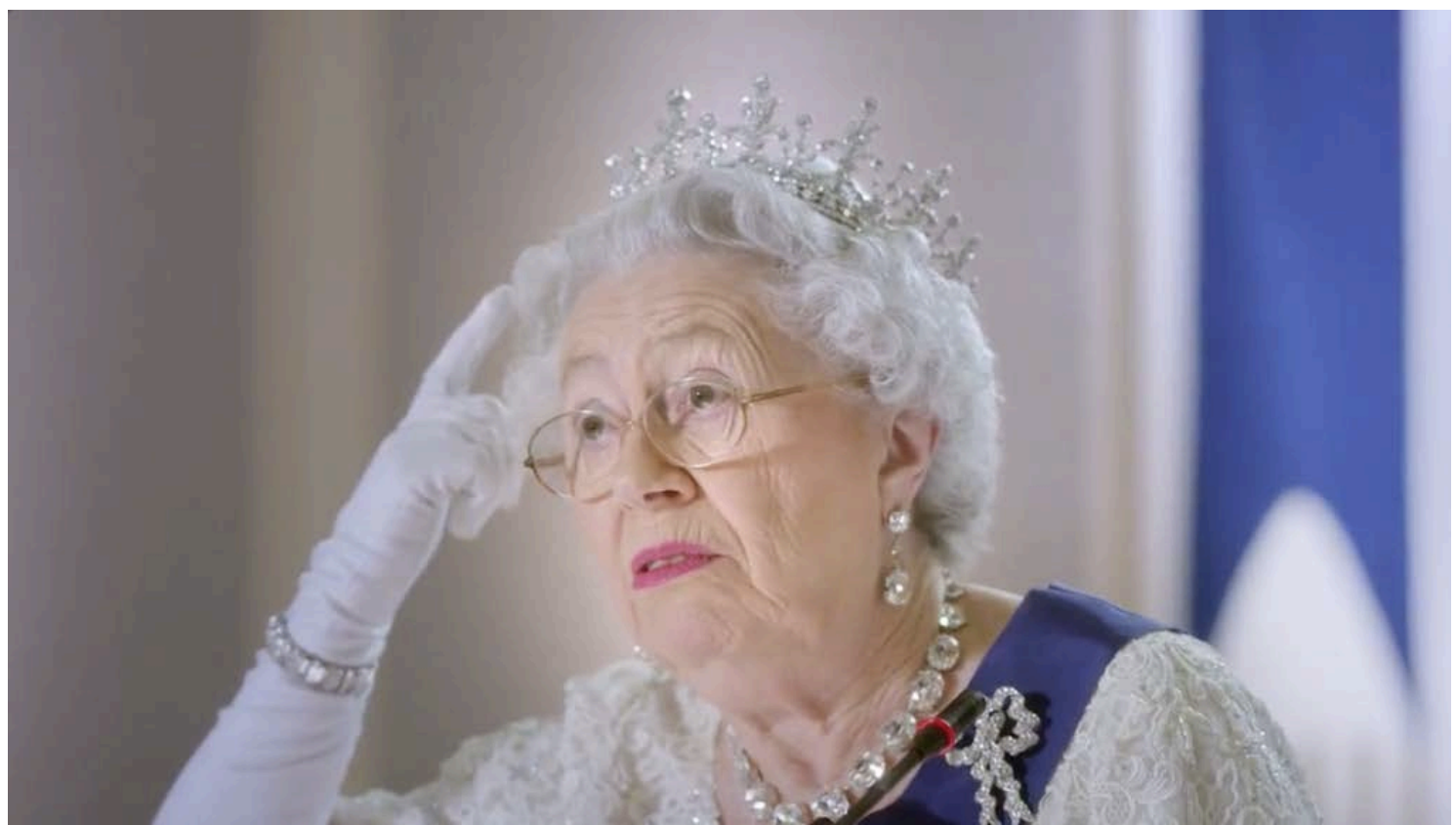

Şekil 4.4: TV reklam filminden ekran görüntüleri (URL 1)

Queen Central Park projesinin reklam filminde gösterenler central park ve kraliçe tacıdır (Çizelge 4.1). Gösterge ise bu gösterenlerin tüketicinin zihinlerindeki anlamlarıdır. İlk olarak, projenin isminde de kullanılan "Central Park", New York City'nin kent kimliğinin önemli bir parçası olan kamusal mekandır. Reklam filminde, İngiltere kraliçesi rolündeki oyuncu "Central Park'ın bir benzeri yapılcaksa o İngiltere'de olmalıdır, İstanbul'da nereden çıktı" demektedir (Şekil 4.4.). Ancak, New York City'nin landmarkı olmuş bir park alanının taklidinin başka yerlerde kopyalanması mimari açıdan yersizleşme ${ }^{4}$ kavramıyla ele alınabilir. Diğer bir yandan, projeye ismini vermesine rağmen projede Central Park'la karşılaştırılabilecek bir yeşil alan tasarımı da yoktur. Burada, New York gibi yoğun yapılaşması olan bir kentin yeşil alanı olan parkın imgesi İstanbul'daki tüketiciyi çekmek için kullanılmıştır. Ancak, bu konseptin projenin isminde olmaktan öteye gidemediği görülmektedir. İkinci gösteren olarak ise reklamda, kraliçe kendi tacını göstererek projenin mimarisinde taç vardır diyor. Çok katlı olan projenin son katlarının ışıklandırılarak oluşturulan parıltı taç imgesine benzetilmiştir (Şekil 3.3). Burada kullanılan taç imgesi mimari açıdan bir değer taşımamasına rağmen projenin sloganı İstanbul taçlanıyor olarak kullanılmıştır. Kısacası, reklamda kullanılan göstergeler projenin mimari özellikleriyle değil, toplumda etkili olacağı düşünülen imgelerle tasarlanmıştır ki bu imgelerin aslında birbiriyle de ilişkileri yoktur. Reklamda sunulan mimari İstanbul kent kimliğinin bir parçası olarak ele alınmazken sadece bir parıltı üzerinden kraliçelere layık bir proje olarak tüketiciyi etkilemeye çalışmıştır. Ayrıca, projenin isminde Central Park vurgusu olmasına rağmen reklamda projenin sözde yeşil alanı gösterilmemiştir.

Bu örnekte olduğu gibi reklam dünyasının karşımıza çıkardığı örneklerden görüyoruz ki projeler bir mimari kimliğin parçası olarak değil simülakra ${ }^{5}$ mekanların göstergeleri ile

\footnotetext{
${ }^{4}$ Koçyiğit (2007)'e göre, yersizleşme: "yerleri yer yapan niteliklerin giderek azaldığı; insanın çevresine bakarak nerede, hangi kültürel yapıya, tarihsel sürece göre oluşmuş, bir çevre içerisinde olduğunu anlayamadığı; buna bağlı olarak aidiyet, kimlik, özgül deneyim gibi sorunlarla karşılaştığı sürecin adıdır."

${ }^{5}$ Simülakra kavramı için bknz. Baudrillard, J., 2011. Simülakrlar ve Simülasyon. 7. dü. İstanbul: Doğu Batı Yayınları
} 
tasarlanmakta ya da pazarlanmaktadır. Konutun mimari özellikleri yerine kraliçe ve tacının verdiği prestij etkisiyle tüketicinin etkilenmeye çalışılması toplumun kimliğinin de değişmekte olduğunun bir göstergesidir diyebiliriz. Çünkü artık toplum, satın alacağı konuttan çok onun sağlayacağı ayrıcalık ile ilgilenmeye başlamıştır.

\begin{tabular}{|c|c|c|c|}
\hline \multicolumn{2}{|l|}{ Proje } & \multicolumn{2}{|c|}{ Queen Central Park } \\
\hline \multicolumn{2}{|c|}{ Proje Künyesi } & \multicolumn{2}{|c|}{$\begin{array}{l}\text { Proje yılı: } 2018 \\
\text { Reklam yılı: } 2016 \\
\text { Yer: İstanbul - Şişli } \\
\text { Arsa alanı: } 26.000 \mathrm{~m}^{2} \\
\text { Ünite sayısı: } 1.080 \\
\text { Firma: Sinpaş GYO } \\
\text { Mimari: Tago Architects }\end{array}$} \\
\hline \multirow[t]{6}{*}{ Reklam } & \multirow[t]{5}{*}{ Gösterenler } & $\begin{array}{l}\text { Görsel } \\
\text { metin }\end{array}$ & Yapının ışıltılı görseli, kraliçe ve kraliçe tacı \\
\hline & & Başlık & - \\
\hline & & Slogan & İstanbul taçlanıyor. \\
\hline & & $\begin{array}{l}\text { Yazilı } \\
\text { metin }\end{array}$ & - \\
\hline & & $\begin{array}{l}\text { Sözlü } \\
\text { metin }\end{array}$ & $\begin{array}{l}\text { "Central Park'ın bir benzeri yapılacaksa o İngiltere'de } \\
\text { olmalıdır, İstanbul'da nereden çıktı" } \\
\text { "Kraliçeleri Bile Kıskandıracak Bir Yaşam" }\end{array}$ \\
\hline & Gösterilen & \multicolumn{2}{|r|}{ 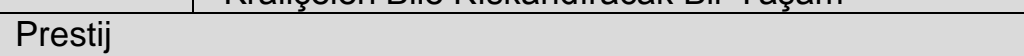 } \\
\hline
\end{tabular}

Çizelge 4.1: Queen Central Park proje reklamı çözümlemesi

\subsection{Marina Ankara Konur Projesi Reklamı}

İkinci örnek olarak ele alınan Marina Ankara Projesi ise diğer bir çok örnekte karşılaşılacağı gibi o yere ait olmayan bir mekansal özelliğin varmış gibi gösterilmesi ve bu yöntemle Ankara'daki başka birçok projeden farklılaştırılmaya ve dikkat çekmeye çalışıldığını göstermesi için seçilmiştir. Reklamın seçimindeki diğer önemli nokta ise bir toplumsal kimlik yönlendirmesi yapıyor olmasıdır.
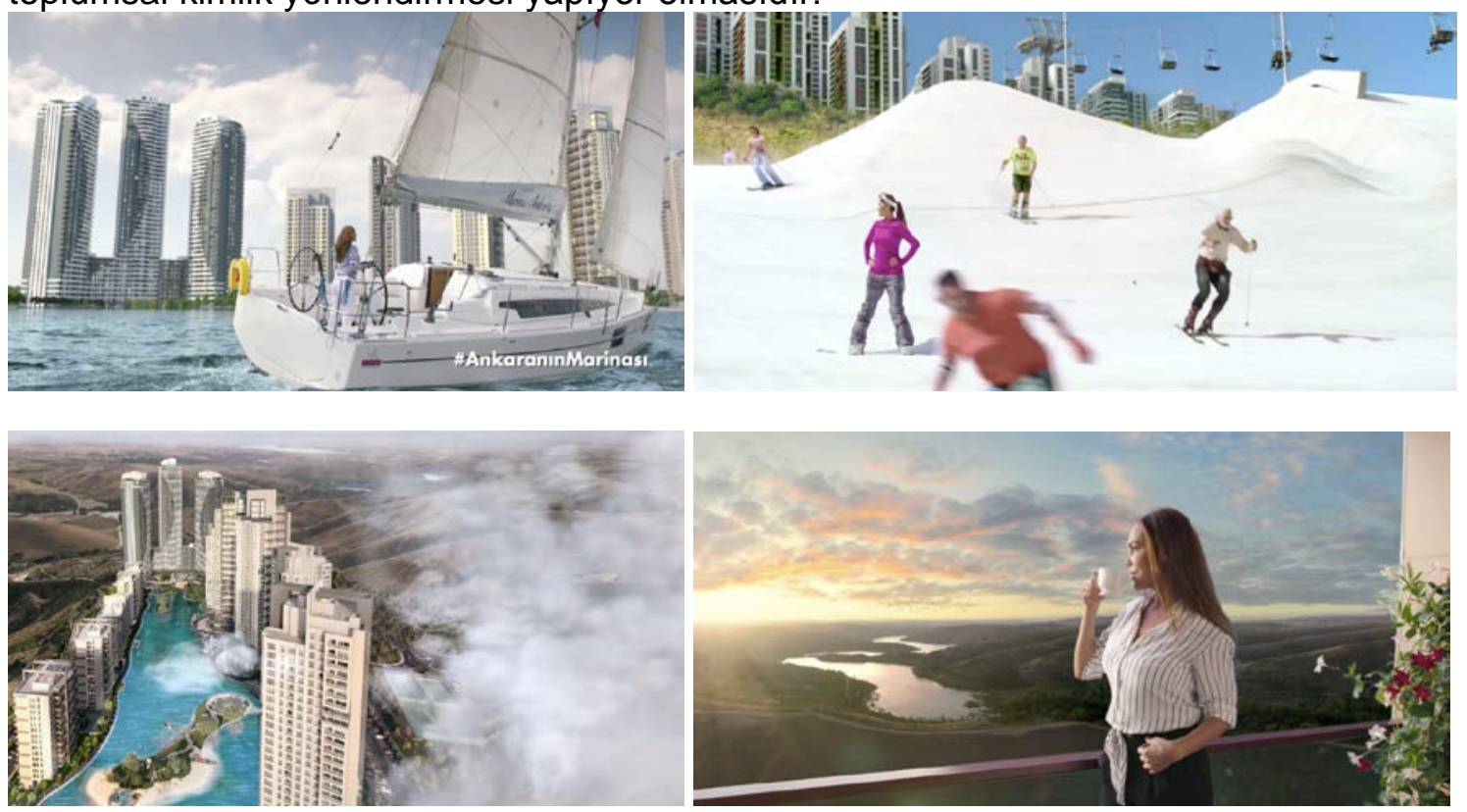

Şekil 4.4: TV reklam filminden ekran görüntüleri (URL 2) 
Erken 21. Yüzyılda Mekansal ve Toplumsal Kimliklerin Değişimini Büyük Ölçekli Konut Projeleri Reklamları Üzerinden Okumak Reading the Change of Spatial and Social Identities in the Early 21st Century through Advertisements on Large-Scale Housing Projects

\begin{tabular}{|c|c|c|c|}
\hline \multicolumn{2}{|l|}{ Proje } & \multicolumn{2}{|c|}{ Marina Ankara } \\
\hline \multicolumn{2}{|c|}{ Proje Künyesi } & \multicolumn{2}{|c|}{$\begin{array}{l}\text { Proje yılı: } 2018 \\
\text { Reklam yılı: } 2016 \\
\text { Yer: Ankara - Çankaya } \\
\text { Arsa alanı: } 120.533 \mathrm{M}^{2} \\
\text { Ünite sayısı: } 2.600 \\
\text { Firma: Sinpaş GYO } \\
\text { Mimari: Evrenol Mimarlık, } \\
\text { Sabri Paşayiğit Design Office }\end{array}$} \\
\hline \multirow[t]{6}{*}{ Reklam } & \multirow[t]{5}{*}{ Gösterenler } & $\begin{array}{l}\text { Görsel } \\
\text { metin }\end{array}$ & $\begin{array}{l}\text { Proje çevresinde marina görüntüsü, kayak merkezi } \\
\text { görüntüsü, proje alanının gerçek olmayan kuşbakışı } \\
\text { görüntüsü, Hülya Avşar ... }\end{array}$ \\
\hline & & Başlık & \\
\hline & & Slogan & Ankara'nın Marinası Bir Başka Yaşaması \\
\hline & & Yazılı metin & \\
\hline & & Sözlü metin & $\begin{array}{l}\text { Maviye yelken açmak, tropik ada, eymir gölü } \\
\text { manzarası, kayak yapma sefası, }\end{array}$ \\
\hline & Gösterilen & \multicolumn{2}{|c|}{ Projenin abartılarak gösterilen sosyal alanları, prestij, statü } \\
\hline
\end{tabular}

Çizelge 4.2: Marina Ankara proje reklamı çözümlemesi

Marina Ankara projesinin reklamındaki ana gösteren "marina" dır (Çizelge 4.2.). Bu proje, Ankara'nın coğrafyasında bulunmayan ancak imgesel değeri yüksek marina, kayak alanı gibi mekanlar ile pazarlanmaktadır. Projede tasarlanmış havuz bir marina gibi gösterilmektedir ancak bu göstergenin mimari olarak gerçek bir karşılığı bulunmamaktadır. Benzer şekilde reklamda sunulan kayak alanı da yapay bir kayak pistidir. Bu proje, Ankara'nın mekansal kimliğinde olmayan mimari elemanlarla bulunduğu çevrenin fiziksel özellikleri düşünülmeden herhangi bir yerde tasarlanmış ve Ankara için gerçek olamayacak bir mekanı tüketicisine sunmaktadır (Şekil 4.4). Aynı zamanda bu mekanın içerisinde yeni bir gündelik yaşamı tüketicisine özendirmektedir. Reklamdaki diğer bir gösterge de Hülya Avşar'ın toplumdaki imgesidir (Şekil 4.4). Bu projede konut sahibi olmakla Hülya Avşar'ın toplumun gözündeki statüsüyle aynı olunacağı hissi tüketiciye verilmektedir. Bu proje reklamından da gördüğümüz üzere kentlerdeki konut alanlarının kimliği, kimliksiz projelerle değişmektedir. Aynı zamanda yeni inşa edilen projelerde yeni bir yaşam kimliği de inşa edilmeye çalışılmaktadır.

\subsection{Bosphorus City - Bursa Modern Konut Projelerinin Reklamı}

Bosphorus City projesinin reklamı tek başına ele alındığında ilk iki proje reklamında gördüğümüz gibi kentsel imge değeri yüksek bir mimari öğenin projede varmış gibi gösterilmeye çalışılması olarak ele alınabilir. Bu örneği farklılaştıran durum ise Bursa Modern projesi ile birlikte ele alındığında (Çizelge 4.3.), birbirine benzer ve kentsel dokudan bağımsız tasarlanmış büyük ölçekli konut projelerinin tüketiciye sunulurken bambaşka göstergeler kullanılarak projelerin farklılaştırılması ve tercih edilir olabilmesinin sağlanmaya çalışılmasıdır. 


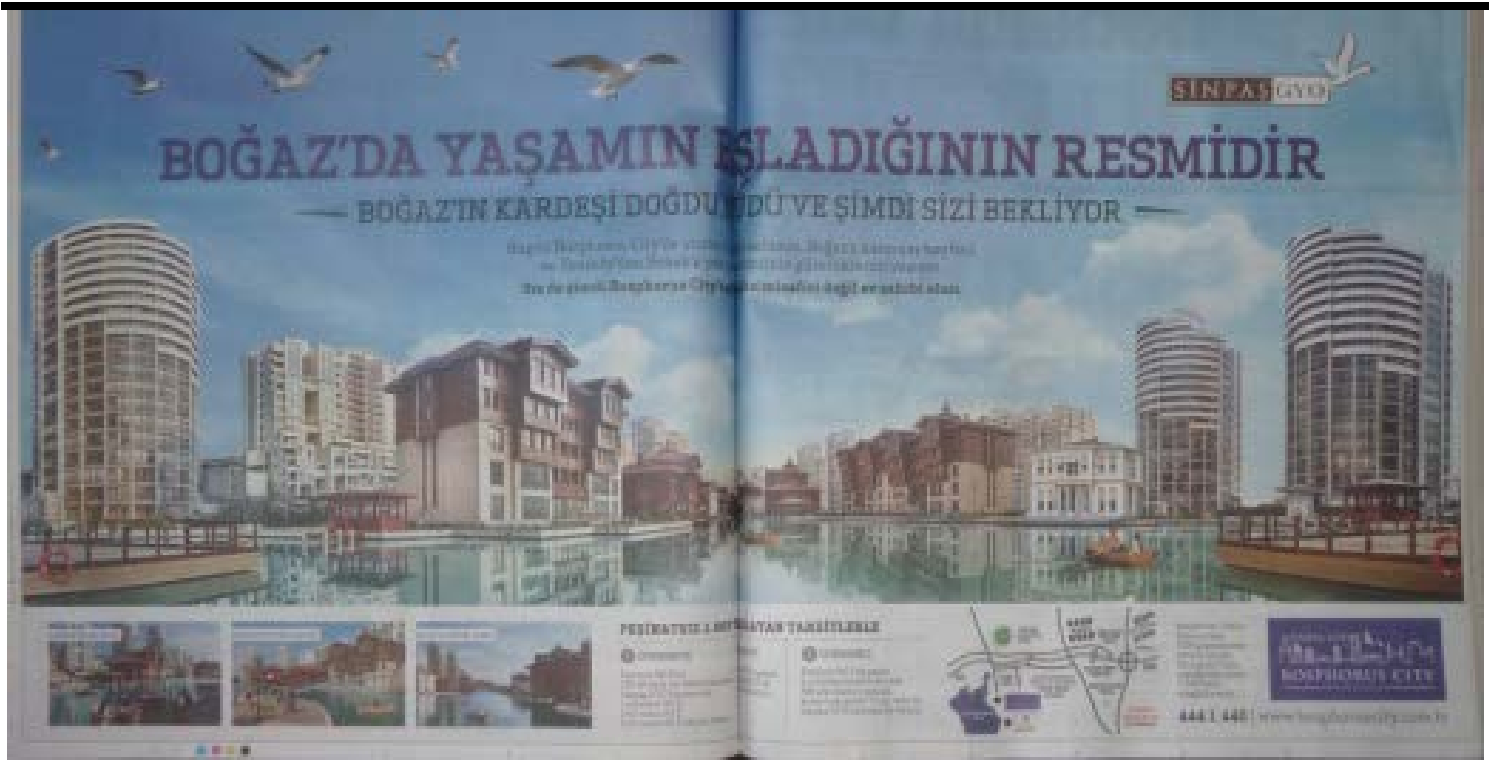

Şekil 4.5: Bosphorus City projesi gazete reklamı (Hürriyet Gazetesi, 25 Şubat 2012, syf. 26-27)

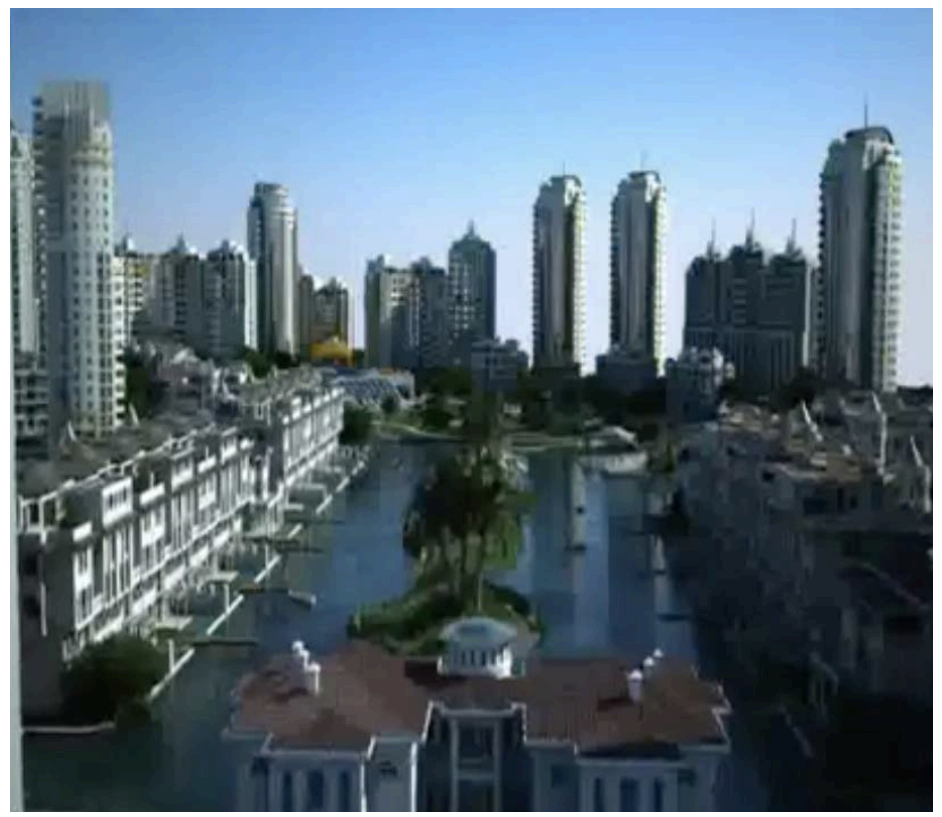

Şekil 4.6. TV reklam filminden ekran görüntüleri (URL 4)

Bosphorus City projesi İstanbul, Küçükçekmece'de, Bursa Modern ise Bursa'da aynı inşaat firması tarafından inşa edilmiş ve aynı mimarlık ofisi tarafından tasarlanmış iki projedir. Projeler birbirinden farklı fiziksel çevrede hatta farklı kentlerde olmalarına rağmen projelerin konut sayısı hariç vaziyet planı kararları ve konut plan tipleri neredeyse aynıdır. İki projede de orta alandaki havuz etrafında alçak katı, dış cephesi ahşap malzeme ile kaplanmış yapılar yer alırken onların arkasında benzer ölçekte çok katlı yapılar vardır.

Projelerin mimarisindeki benzerliğe rağmen Bosphorus City projesi reklamı İstanbul'da kendine benzer onlarca proje arasından tercih edilebilir olmak için, başka birçok projede yer alan veya alabilecek havuz alanını İstanbul Boğazı ile özdeşleştirilmeye çalışarak bir satış stratejisi izlemiştir, havuzun etrafındaki alçak katlı konut bloklarını İstanbul boğaz yalılarıyla ve havuzun etrafındaki bölgeleri de boğaz semtlerinin isimleri ile adlandırarak tüketici üzerinde İstanbul Boğazı niteliğine sahip bir konut projesinde 
yaşayabileceği duygusunu uyandırmaya çalışmıştır (Şekil 4.5). Benzer bir mimari kurguya sahip Bursa Modern projesinde ise benzer bir satış stratejisi kullanılmamış potansiyel tüketiciye bu proje ile yeni bir Bursa ve yeni bir yaşam alanı mesajı verilmeye çalışıldığı görülmüştür (Şekil 4.6). Kısacası, projelerin mimari niteliklerini tartışmadığımız bu çalışma kapsamında benzer konut projelerinin satış stratejilerinde gerçek olmayan imgelerin kullanıldığını bu iki benzer proje sayesinde görebilmekteyiz. İlk projede boğaz simülasyonunu mekansal kimlik açısından değerlendirilirken, diğer projede yeni yaşam tarzı imajını toplumsal kimlik açısından ele alınabilir ve sonradan yüklenmeye çalışılan kimlik kaygısının aslında kimliksiz yaşam alanları ve yaşam tarzı ortaya çıkarmakta olduğu söylenebilmektedir.

\begin{tabular}{|c|c|c|c|}
\hline \multirow{2}{*}{\multicolumn{2}{|c|}{$\begin{array}{l}\text { Proje } \\
\text { Proje Künyesi }\end{array}$}} & \multirow{2}{*}{\multicolumn{2}{|c|}{$\begin{array}{l}\text { Bosphorus City } \\
\text { Proje yılı: } 2008 \text { - } 2011 \\
\text { Reklam yıll: } 2012-2015 \\
\text { Yer: İstanbul - Küçükçekmece } \\
\text { Arsa alanı: } 246.000 m^{2} \\
\text { Ünite sayısı: } 2.796 \\
\text { Firma: Sinpaş GYO } \\
\text { Mimari: Evrenol Mimarlık }\end{array}$}} \\
\hline & & & \\
\hline \multirow[t]{6}{*}{ Reklam } & \multirow[t]{5}{*}{ Gösterenler } & Görselmetin & İstanbul Boğazı simülasyonunda proje görseli \\
\hline & & Başlık & Boğaz'da yaşamın başladığının resmidir \\
\hline & & Slogan & $\begin{array}{l}\text { Boğaz'ın kardeşi doğdu büyüdü ve şimdi sizi } \\
\text { bekliyor }\end{array}$ \\
\hline & & Yazılı metin & $\begin{array}{l}\text { Mekanları İstanbul Boğazı imgeleriyle } \\
\text { isimlendirme } \\
\text { Boğaz'ın misafiri değil ev saihib olun }\end{array}$ \\
\hline & & Sözlü metin & Emirgan'da çay keyfi, Boğaza karşı gezinti. \\
\hline & Gösterilen & \multicolumn{2}{|c|}{ İstanbul Boğazında yaşam } \\
\hline \multicolumn{2}{|l|}{ Proje } & \multicolumn{2}{|c|}{ Bursa Modern } \\
\hline \multicolumn{2}{|c|}{ Proje Künyesi } & \multicolumn{2}{|c|}{$\begin{array}{l}\text { Proje yılı: } 2007-2010 \\
\text { Reklam yılı: } 2015 \\
\text { Yer: Bursa - Yeşilşehir } \\
\text { Arsa alanı: } 107.785 \mathrm{~m}^{2} \\
\text { Ünite sayısı: } 1980 \\
\text { Firma: Sinpaş GYO } \\
\text { Mimari: Evrenol Mimarlık }\end{array}$} \\
\hline \multirow[t]{4}{*}{ Reklam } & \multirow[t]{3}{*}{ Gösterenler } & $\begin{array}{l}\text { Görsel } \\
\text { metin }\end{array}$ & Proje görselin görüntüler, yaşam alanları, \\
\hline & & Yazılı metin & $\begin{array}{l}\text { Mutlu evler hepimize } \\
\text { Yeni Bursa burası }\end{array}$ \\
\hline & & Sözlü metin & Bursanın çocukları yeşile kavuşuyor.. \\
\hline & Gösterilen & Ayrıcalık yaş & \\
\hline
\end{tabular}

\subsection{Ege Boyu - Ege Yakası - Ege Vadisi Projelerinin Reklamı}

Ege imgesi ile satış stratejisi oluşturulmuş bu üç konut projesi reklamının seçilmiş olmalarının sebebi ise herhangi bir yerdeki herhangi bir konut projesinin olduğundan farklı gösterilerek ve sahip olduğundan farklı kimlik öğelerinin yüklenmeye çalışılması ile satışının ve reklamının yapılabildiğini gösterebilmektir (Çizelge 4.4.). Farklı bir yöreye ait mimari kimlik öğeleri başka bir yerde tekrar kullanıldığında bağlamından koparıldığı için aynı değeri taşıyamaz.

Ege ismini taşıyan bu üç projenin ikisi İstanbul'da farklı yakalarda biri de Ankara'da inşa edilmiş projelerdir. Benzer ölçeklerdeki üç projede kendi sınırları içerisinde, Ege'nin tarihi mimari dokusu, Ege'nin topografyası, iklimi, dokusuyla hiç bir ilişkisi olmayan herhangi bir konut projesi olarak tasarlandıktan sonra satış stratejisi gereği 
Ege imgesi ile pazarlanmaya çalışılmaktadır (Şekil 4.7-8-9). Mimarilerinde Ege bölgesinin geleneksel mimarisinden çözümler taşımazken, reklamdaki gösterenler sadece güçlü sloganla birlikte, çiçekler ve mavi beyaz renklerdeki boya ve birkaç ahşap kepenktir. Bu gösterenler aracılığıyla Ege imgesi yaratılmaya çalışımış ve yoğun yapılaşmış büyük kentlerdeki tüketicinin dikkatleri çekilmeye çalışılmıştır. Ancak, farklı kentlerde üretilen simülakra projelerle bir mekan kimliğinden söz edilemezken, mekanların kimlikleri kaybedilmektedir diyebiliriz.

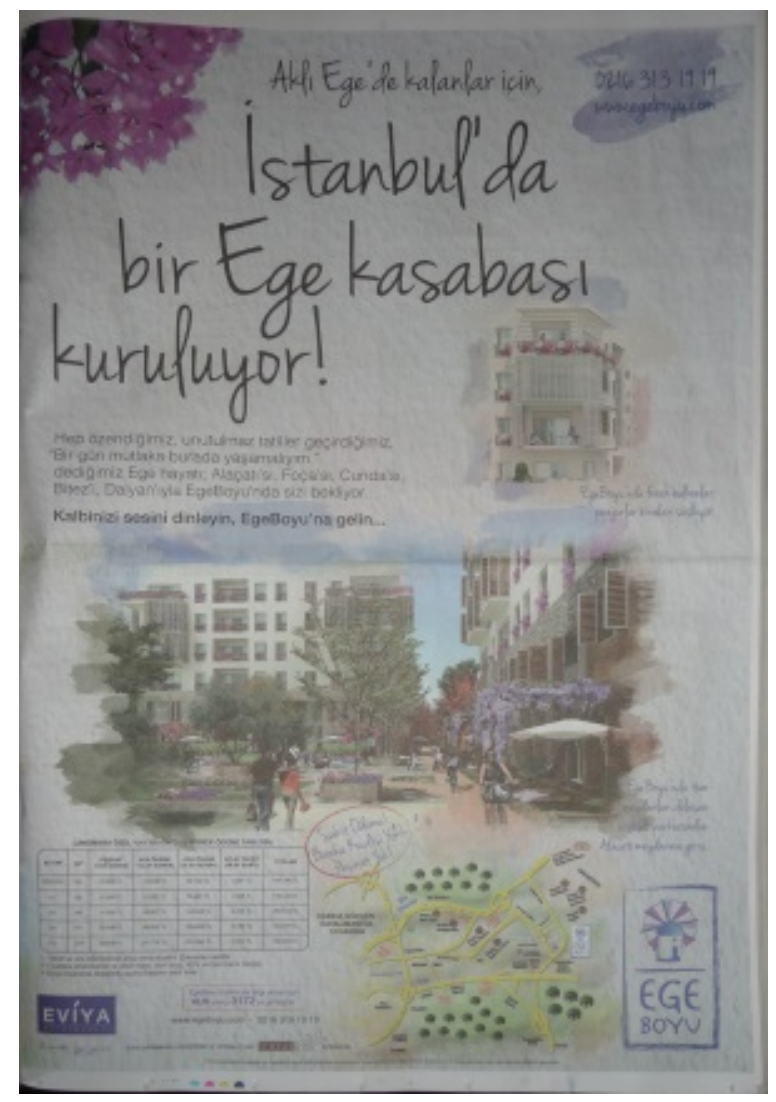

Şekil 4.7: Ege Boyu Gazete Reklamı (Hürriyet Gazetesi, 22 Eylül 2012, syf. 7) 


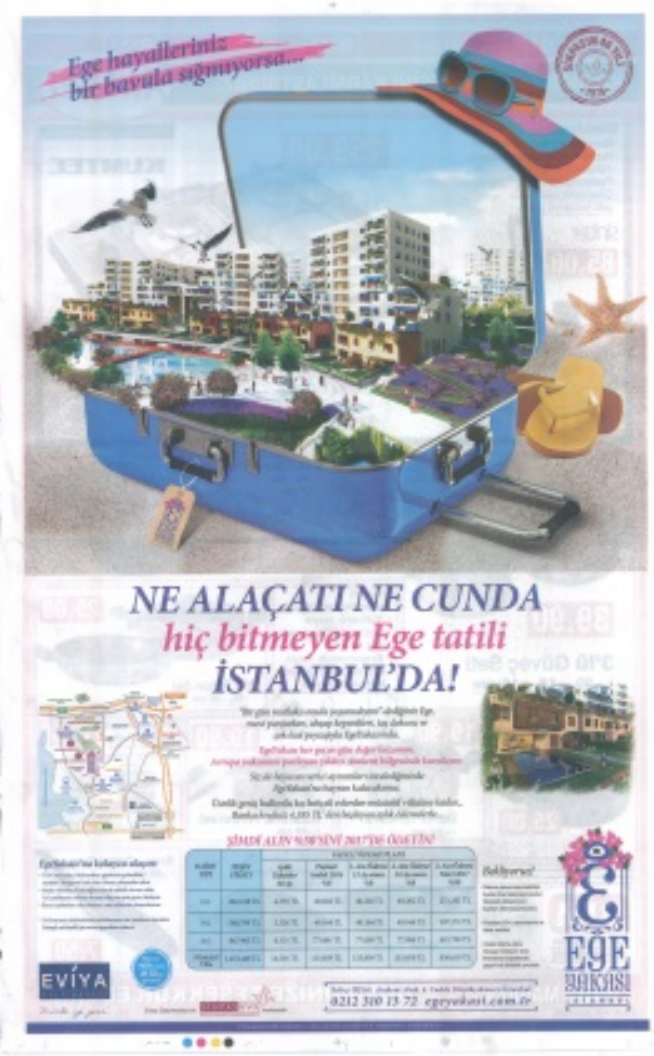

Şekil 4.8: Ege Yakası Gazete Reklamı (Hürriyet Gazetesi, 18 Eylül 2014)

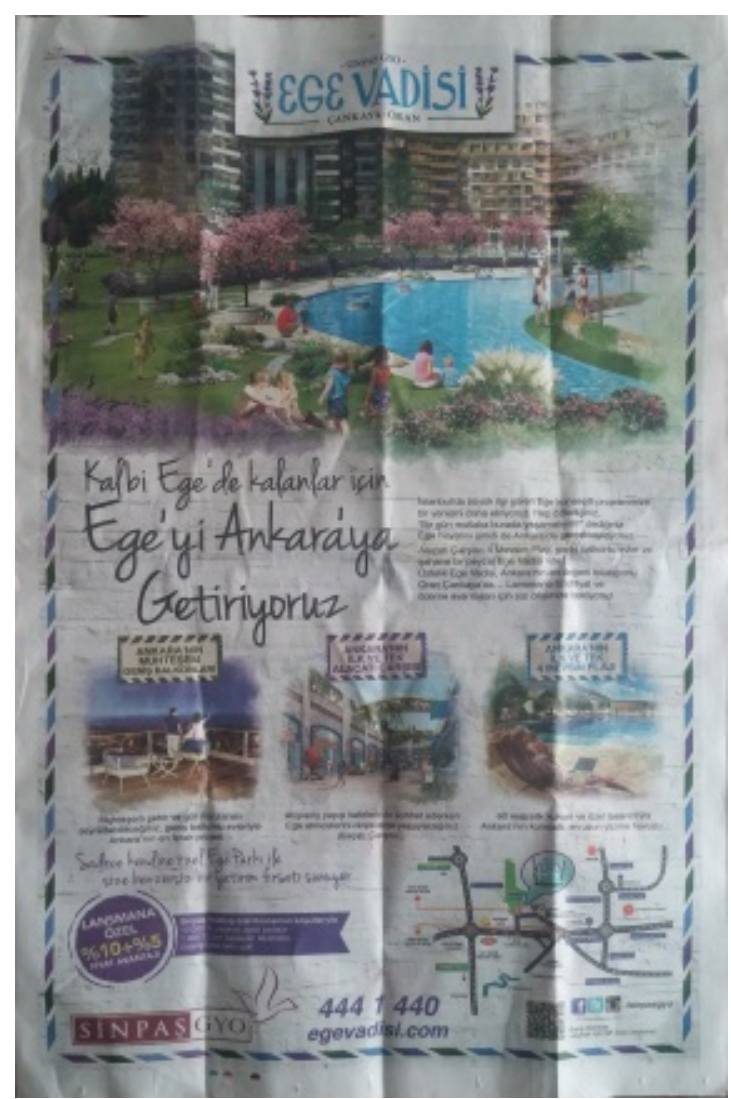

Şekil 4.9: Ege Vadisi Gazete Reklamı (Hürriyet Gazetesi, 14 Mayıs 2016, syf 5) 


\begin{tabular}{|c|c|c|c|}
\hline Proje & \multicolumn{3}{|l|}{ Ege Boyu } \\
\hline $\begin{array}{l}\text { Proje } \\
\text { Künyesi }\end{array}$ & \multicolumn{3}{|c|}{$\begin{array}{l}\text { Proje yılı: } 2011 \text { - } 2013 \\
\text { Reklam yılı: } 2012 \\
\text { Yer: İstanbul } \\
\text { Sancaktepe } \\
\text { Arsa alanı: } 40.548 \text { M² } \\
\text { Ünite sayısı: } 644 \\
\text { Firma: Eviya - Sinpaş } \\
\text { Mimari: Era Mimarlık }\end{array}$} \\
\hline \multirow[t]{5}{*}{ Reklam } & \multirow[t]{4}{*}{ Gösterenler } & $\begin{array}{l}\text { Görsel } \\
\text { metin }\end{array}$ & Projenin görseli ege imgeleriyle birlikte \\
\hline & & Başlık & İstanbul'da bir ege kasabası kuruluyor \\
\hline & & Slogan & İstanbul'un yeni yaşam kültürü \\
\hline & & $\begin{array}{l}\text { Yazilı } \\
\text { metin }\end{array}$ & $\begin{array}{l}\text { Bir gün mutlaka burada yaşamalıyım dediğimiz } \\
\text { Ege hayatı; Alaçatı'sı, Foça'sı, Cunda'sı, } \\
\text { Bitez'i, Dalyan'ıyla Ege Boyu'nda sizleri } \\
\text { bekliyor. }\end{array}$ \\
\hline & Gösterilen & \multicolumn{2}{|c|}{ Ege yaşamı } \\
\hline Proje & \multicolumn{3}{|l|}{ Ege Yakası } \\
\hline $\begin{array}{l}\text { Proje } \\
\text { Künyesi }\end{array}$ & \multicolumn{3}{|c|}{$\begin{array}{l}\text { Proje yılı: } 2016 \\
\text { Reklam yılı: } 2014 \\
\text { Yer: İstanbul Küçükçekmece } \\
\text { Ünite sayısı: } 563 \\
\text { Firma: Sinpaş GYO } \\
\text { Mimari: Teğet Mimarlık }\end{array}$} \\
\hline \multirow[t]{4}{*}{ Reklam } & \multirow[t]{3}{*}{ Gösterenler } & $\begin{array}{l}\text { Görsel } \\
\text { metin }\end{array}$ & $\begin{array}{l}\text { Kumsal üzerindeki bavulun içerisine } \\
\text { yerleştirilmiş proje görseli }\end{array}$ \\
\hline & & Slogan & $\begin{array}{l}\text { Ne Alaçatı ne Cunda hiç bitmeyen Ege tatili } \\
\text { İstanbul'da }\end{array}$ \\
\hline & & Yazilı & Ege hayalleriniz bir bavula sığmıyorsa \\
\hline & \multicolumn{2}{|l|}{ Gösterilen } & Ege tatili, İstanbul'da Ege yaşamı \\
\hline Proje & \multicolumn{3}{|l|}{ Ege Vadisi } \\
\hline $\begin{array}{l}\text { Proje } \\
\text { Künyesi }\end{array}$ & \multicolumn{3}{|c|}{$\begin{array}{l}\text { Proje yılı: } 2018 \\
\text { Reklam yılı: } 2016 \\
\text { Yer: Ankara - Çankaya } \\
\text { Arsa alanı: } 26900 \text { m2 } \\
\text { Ünite sayısı: } 887 \\
\text { Firma: Sinpaş GYO } \\
\text { Mimari: Evrenol Mimarlık }\end{array}$} \\
\hline \multirow[t]{4}{*}{ Reklam } & \multirow[t]{3}{*}{ Gösterenler } & $\begin{array}{l}\text { Görsel } \\
\text { metin }\end{array}$ & Proje görselin görüntüler, yaşam alanları, \\
\hline & & Slogan & $\begin{array}{l}\text { Kalbi Ege'de kalanlar için Ege'yi Ankara'ya } \\
\text { getiriyoruz }\end{array}$ \\
\hline & & $\begin{array}{l}\text { Yazılı } \\
\text { metin }\end{array}$ & $\begin{array}{l}\text { Ankara'nın ilk ve tek Alaçatı Çarşısı } \\
\text { Ankara'nın ilk ve tek dört mevsim plajı }\end{array}$ \\
\hline & Gösterilen & \multicolumn{2}{|c|}{ Ankara'da Ege yaşamı } \\
\hline
\end{tabular}

Çizelge 4.4: Ege Boyu, Ege Yakası, Ege Vadisi projelerinin reklam çözümlemesi 


\section{SONUÇ}

Reklamda ürün bir imge olarak karşımıza çıkarılır ve onu temsil eder, sonrasında ise artık o imge ürünün kendisine dönüşür, üründen çok imgenin taşıdığı anlam tüketilmek istenen olur. Kentlerin, özellikle İstanbul'un değişimi üzerinde reklamlarda kullanılan imgelerin etkisi çoktur. Her geçen gün sayısı artan konut projeleri artık barınma ihtiyacını karşılayan ev değil imgesel değerlere sahip tüketim metalarıdır. Tüketim toplumunun bireyleri konutun taşıdığı imge değerine göre tercihlerini yaparlar. Özellikle İstanbul'un hemen her noktasında ve diğer büyükşehirlerde benzer imajlara sahip konut projeleri inşa edilirken reklamın gücü bireyleri etkisi altına alarak bu projeleri talep edilir hale getirir. Büyük ölçekli konut projelerinin reklamları aslında simülakr mekanları potansiyel tüketicisine sunar. Bu bağlamda, Baudrilard (2011)'a göre, günümüzün temel sorunu da gerçeğin üretimi ve yeniden üretimi denen şeydir. Maddi üretim günümüzde hipergerçek bir şeye dönüşmüştür. Ayrıca, 2000'lerde kentte konut sahibi olmak, ekonomik bir yatırımın yanı sıra sınıfsal kimlik inşa etme aracı olarak görülmeye başlanmıştır. Bu kapsamda, reklamlar, konut tüketimini ve konut beğenisini, günlük hayatın her yerinde karşımıza çıkartmaktadır. Kısacası, reklamlarla sürekli bir konut tüketimi özendirilmesi yapılmaktadır ve reklamda sunulan konut yeni kapitalist düzene uygun bir yaşam biçimini özendirmektedir.

Diğer bir yandan projeler standart özellikteki konut planları ve farklı ölçeklerdeki yapılar olmakla birlikte bulundukları bağlama göre tasarlanmadıkları göze çarpmaktadır. Yer, iklim, bitki örtüsü, kültürel yapısı gibi kendi bağlamından yoksun tasarlanmış projelerin reklam stratejisi kapsamında başka bağlamlara özgü kimlik öğeleri ile pazarlanmakta olduklarını görmekteyiz. Yere özgü olan imge değerlerinin bağlamsız bir şekilde projelere yüklenmeye çalışılmasının kentlerde sahte mekansal kimlikler oluşturmaya çalıştığını ve tüketiciyi kandırılmaya çalışıldığını görmekteyiz. Birbirine benzer özelliklerde tasarlanmış bir çok konut projesi birbirinden ayrışabilmek için toplumdaki güçlü imge değerleri üzerinden satış stratejisi gerçekleştirmektedir. Simüle edilmiş mekanlar ya da sadece reklamda kullanılan sloganlar aracılığıyla bir kimlik üretimi gerçekleştirmeye çalışan bu projeler mimari açıdan kimliksiz olarak ele alınabileceği gibi bir yandan da yüksek katlı ve yüksek yoğunluklu yapılaşmaları, güvenlikli siteler olmaları, kendi sosyal mekanlarını içinde barındırarak dışa kapalı bir mimari çözüm geliştirmeleri açısından kentlere yeni kimliksiz bir kimlik dayattığı söylenebilir.

Tekeli (1991), kent kimliğinin oluşumunu tarihsel bir olgu olarak görmekte ve kent kimliğinin zaman içinde farklı katmanların uyumlu ve anlamlı bir bütün oluşturmasıyla gerçekleştiğini belirtmektedir. Bu nedenle kente yeni bir kimlik kazandırmak yerine önce onun bütün boyutlarıyla deşifre edilmesi, var olan özgün kimliğini kuran değerlerin keşfedilmesi, bu değerlerin güncel koşullar ve gerekliliklerle bütünleştirilmesi ve böylece kent kimliğinin sürekliliğinin sağlanması pek çok açıdan daha uygun bir tutum olacaktır demektedir. (Birol,2007). Ancak, projelerin reklamlarında gördüğümüz üzere, büyük ölçekli konut projeleri kentsel mekanın kimliğini ve toplumsal kimlikleri değiştirmeye yönelik bir kurguyla işlemektedir. Bu değişim reklamlar aracılığıyla özendirilmektedir. Konut kavramının değişmesi ve büyük ölçekli konut alanlarının giderek artması konutun ve kentlerin niteliğini ciddi şekilde değiştirmeye başlamıştır. Aynı zamanda değiştirilen konut alanları içerisinde yeni bir toplumsal kimlik tasarlanmaktadır. Sermaye bir yandan daha çok inşa ederek gelir sağlarken bir yandan da tasarlanan projelerle toplumu gündelik yaşamlarında daha çok tüketen bir topluma çevirmektedir. 
KAYNAKLAR

Althusser, Louis, Ideoloji ve Devletin Ideolojik Aygıtları, Çev: Alp Tümertekin, İthaki Yayınları, İstanbul, 2014.

Barthes, Roland, Göstergebilimsel Serüven. Çev: Mehmet Rifat, Sema Rifat, Yapı Kredi Yayınları, İstanbul, 2014.

Baudrillard, Jean, Simülakrlar ve Simülasyon, Doğu Batı Yayınları, İstanbul, 2011.

Baudrillard, Jean, Tüketim Toplumu, Çev: Hazal Deliceçaylı, Ferda Keskin, Ayrıntı Yayınları, İstanbul, 2013.

Baudrillard, Jean, Nesneler Sistemi, Boğaziçi Üniversitesi Yayınevi, İstanbul, 2014.

Birol, Gaye, Bir Kentin Kimliği Ve Kervansaray Oteli Üzerine Bir Değerlendirme, Arkitekt Dergisi, sayı: 514, s. 46-54, Kasım-Aralık 2007.

Catells, Manuel, Kent Sınıf Iktidar, Çev: Asuman Türkün, Phoenix Yayınevi, Ankara, 2014.

Çıkış, Şeniz, "Birinci Ulusal Mimarlık Dönemi İzmir Konutu: Yerellik Ve Melezlik", METU JFA, 28:2, 2011, s. 45-61.

Dağtaş, Banu, Reklam Kültür Toplum, Ütopya Yayınevi, Ankara, 2009.

Dağtaş, Banu, Reklamı Okumak, Ütopya Yayınevi, Ankara, 2012.

Erzen, Jale, N., "Etik-Estetik Arasında Mimari”, Etik - Estetik, Ed. Ayşe Şentürer, Yapı Kredi Yayınları, İstanbul, 2004, s.228-2237.

Harvey, David, Sosyal Adalet ve Şehir, Çev: Mehmet Moralı, Metis Yayınları, İstanbul, 2013.

Kaplan, Seda, Erken 21. Yüzyılda Üretilen Büyük Ölçekli Konut Projelerinin Tanıtımında, Kentsel Konum Manipülasyonu, İstanbul Örneği, Yüksek Lisans Tezi, MSGSÜ, FBE, İstanbul, 2016.

Küçükerdoğan, Rengin, Reklam Nasıl Çözümlenir? Reklam Illetişimde Göstergeler ve Stratejiler, Beta Basım, İstanbul, 2011.

Koçyiğit, Gökhan, Mimarlıkta Yersizleşme ve Yerin Yeniden Üretimi, Doktora Tezi, MSGSÜ Fen Bilimleri Enstitüsü, İstanbul, 2007.

Lefebvre, Henri, Mekanın Üretimi, Çev: Işık Ergüden, Sel Yayıncılık, İstanbul, 2014.

Levi-Strauss, Claude, Mit ve Anlam, Çev: Gökhan Yavuz Demir, İthaki Yayınları, İstanbul, 2013.

Özgen Kösten, E. Yeşim, Kentsel Konut Mekan Dizgesi/Arakesitlerin Dönüşümü, Volga Yayıncılık, Kocaeli, 2016. 
Önem, A. Buket; Kılınçaslan, İsmet, "Haliç Bölgesinde Çevre Algılama Ve Kentsel Kimlik", itüdergisi/a, 4/1, 2005, s. 115-125.

Perouse, J. F., İstanbul Çeperlerinde Yeni Bir "Kentsel Kimlik" Yaratma Çabası: Yerel Adil Düzen'den Globalleşen Piyasa Arayışlarına Başakşehir Hikayesi (1995-2007), IAPS-CSBE Network Kültür ve Mekan Toplantıları Birinci Ulusal Sempozyum, Bahçeşehir Üniversitesi, İstanbul, 14-16 Aralık, 2007, s. 24-28.

Saussure, Ferdinand de, Genel Dilbilim Yazıları, Çev: Savaş Kılıç, İthaki Yayınları, İstanbul, 2014.

Ulu, Ali; Karakoç, İlknur, "Kentsel Değişimin Kent Kimliğine Etkisi", Planlama Dergisi, 2004/3, s.59-66.

Williamson, Judith, Reklamların Dili, Reklamlarda Anlam ve Ideoloji, Çev: Ahmet Fethi, Ütopya Yayınevi, Ankara, 2001.

URL 1, https://queencentralpark.com/

URL 2, http://www.marinaankara.com/\#galeri

URL 3, http://www.bosphoruscity.com.tr/eng/

URL 4, http://www.sinpasbursamodern.com/BasinReklamFilmleri.aspx

Not: Bu yazıda Kaplan, Seda, Erken 21. Yüzyılda Üretilen Büyük Ölçekli Konut Projelerinin Tanıtımında, Kentsel Konum Manipülasyonu, İstanbul Örneği, Yüksek Lisans Tezi, MSGSÜ, FBE, İstanbul, 2016. den yararlanılmıştır.

\section{TEŞEKKÜR}

Proje reklamlarına erişebilmek için gazete arşivlerine başvurduğum "Basın Müzesi" çalışanlarına; makalenin daha nitelikli bir hale gelmesine yardımcı olan hakemlerin görüşlerine teşekkür ederim. 